\title{
HISTORICAL INSTITUTIONALISM AND THE DEVELOPMENT OF SUB-STATE DIPLOMACY IN SOUTH AFRICA
}

\author{
Fritz Nganje ${ }^{1}$
}

\begin{abstract}
This article borrows theoretical insights from historical institutionalism to analyse the development of sub-state diplomacy in the South African context. It identifies the political negotiations that allowed South Africa to make a relatively peaceful transition from apartheid to a democratic dispensation as a critical historical juncture that established the institutional pathway on which subsequent political processes would unfold. Although the Constitution that emerged from this historical moment makes room for semi-autonomous sub-national entities with some degree of competences in foreign affairs, it also deferred to the impulses of the ANC for a centralised system of government. The article argues that, in the context of the ANC's entrenched hegemony in the post-apartheid South African polity, this compromise has translated into a centralised political culture which has shaped the nature, scope, and efficacy of the international involvement of provinces and municipalities. Not only have provincial and local governments been shut out of the foreign policy-making process, but their direct involvement in international relations has also been constrained by the dominant understanding that matters of foreign affairs are the exclusive preserve of the national government. The article concludes by noting that without any significant prospects for a major transformation of the institutional order, provinces like the Western Cape have resorted to creative measures that enable them to by-pass the constraining effects of the system in order to make the most of their international relations.
\end{abstract}

Keywords: South Africa; diplomacy; historical institutionalism; sub-state diplomacy; sub-national governments; paradiplomacy.

Sleutelwoorde: Suid-Afrika; diplomasie; historiese institusionalisme; substaat-diplomasie; subnasionale regerings; paradiplomasie.

\section{INTRODUCTION}

The involvement of sub-national governments (SNGs) in international affairs, referred to here as sub-state diplomacy, ${ }^{2}$ has largely been explained using variables such as globalization, nationalism, regionalism and federalism. In particular,

1 Post-doctoral Research Fellow, SARChI Chair: African Diplomacy and Foreign Policy, University of Johannesburg. E-mail: nganjef@yahoo.com

2 Consistent with the myriad conceptualisations and interpretations of the phenomenon, different terms have been used by scholars to denote the foreign relations of sub-national governments. "Sub-state diplomacy" is used in this article as a fairly neutral term to describe the foreign relations of sub-national governments. 
neo-liberal theories of globalization and economic interdependence interpret the worldwide phenomenon of SNGs developing an international agency as a manifestation of the structural changes that are characteristic of the present epoch. Sub-state diplomacy could thus be explained as a pragmatic response by SNGs to the opportunities and challenges of rapid globalization and economic interdependence, especially in the context of what has been described as the crisis of the nation-state. Other attempts to explain the growing international role of SNGs have emphasized the federal character of the polities within which these units operate. Although it is acknowledged that not all federal constitutions grant foreign policy competences to sub-national entities, in the context of the growing internationalisation of domestic policies, the assumption is that SNGs in federal or semi-federal polities are incentivised by the federal logic of divided sovereignty to develop an active international agency (Lecours 2002:102). In other words, by virtue of their domestic competences in policy areas such as education, health, environmental protection or regional development, sub-national governments are encouraged to acquire an indirect foreign policy competence and become dynamic actors in international relations, even when this is not explicitly provided for in the federal constitution. Still other explanations of sub-state diplomacy focus on the nationalistic ambitions of the sub-national elite. From this perspective, the foreign activities of SNGs are a form of identity politics through which sub-national elites attempt to construct and seek recognition for a distinct personality for their region.

While these different theoretical perspectives give us valuable insights into the nature and different motivations behind the international involvement of SNGs, they fall short of offering satisfactory explanations of the development of sub-state diplomacy in specific political contexts, making it difficult to account for variations in the scope and intensity of the phenomenon between countries, and even within the same country over time. Recent studies by scholars, such as Bursens and Deforche (2010), have attempted to address this gap by borrowing from contemporary institutional theory to propose a framework for explaining variations in the foreign policy competences and international activities of SNGs. The objective of this article is to contribute to this line of scholarly inquiry by using historical institutionalism to explain the manifestation and evolution of substate diplomacy in the South African context. It argues that the nature, scope, and efficiency of the international involvement of South Africa's provincial and local governments has been shaped by the country's constitutional design, which makes room for semi-autonomous sub-national entities, while underscoring the supremacy of the national government over policy issues. Over the years, the political and institutional culture that has developed from this constitutional design has worked to undermine the relative autonomy of sub-national entities, and therefore limited the extent to which they can engage in sub-state diplomacy. The article 
begins with an overview of the literature on sub-state diplomacy to highlight the different explanatory frameworks that have been proposed in understanding and explaining the phenomenon. This is followed by a theoretical discussion on the role of institutions in shaping political outcomes, with a particular focus on historical institutionalism. The third section of the article draws on these theoretical insights to analyse the manifestation and development of sub-state diplomacy in South Africa. The article concludes by summarising and reiterating the key argument made about the effects of South Africa's constitutional design and political culture on the foreign relations of the country's SNGs.

\section{EXPLAINING SUB-STATE DIPLOMACY: A BRIEF REVIEW OF THE LITERATURE}

The diplomacy of SNGs has been interpreted differently by different scholars, reflecting the complexity of a phenomenon which is shaped both by global dynamics and specific national contexts. Early conceptualizations of the foreign relations of SNGs adopted the formal distribution of competence in federal systems as the major explanatory factor of the diplomacy of SNGs. This gave rise to concepts such as micro-diplomacy, paradiplomacy or sub-national diplomacy, which were coined to describe the activities of SNGs in federal states geared towards representing their interests on the international stage (Duchacek 1990:32). From this perspective, the diplomacy of SNGs is simply the external manifestation of the system of shared rule that is characteristic of federal polities. SNGs in federal systems can derive their foreign policy competences from two features of the federal constitutional design. Firstly, as the examples of Germany and Belgium reveal, the diplomacy of some SNGs is rooted in the constitutional distribution of powers over foreign affairs. In these cases, the constitution departs from the traditional practice of concentrating foreign policy competence in the federal government to accord SNGs authority over aspects of foreign policy (Bursens and Massart-Pierard 2009; Hrbek 2009). Secondly, even in federal systems where the constitution assigns authority over foreign policy exclusively to the federal government, SNGs can still develop an international agency on the basis of their domestic competences. As Lecours (2002:102) argues, SNGs, "can use the federal logic of divided sovereignty to argue that certain matters over which they have jurisdiction naturally extend beyond national borders".

Theoretically, it is assumed that SNGs with constitutionally-entrenched foreign affairs competence are more likely to develop a robust international presence compared to their counterparts whose foreign affairs competence are only inferred from other provisions of their constitution. What is more, accounts of sub-state diplomacy that emphasize the distribution of foreign policy competences 
in federal constitutions have often assumed a hierarchy of international activities, in which the foreign relations of SNGs are subordinate to those of the federal government. In this context, conflict between national and sub-national governments over foreign affairs is interpreted as the occasional manifestation of divergent priorities and strategies, which is not uncommon in federal systems and can easily be managed through effective mechanisms of coordination (Lecours and Moreno 2003:289).

Other explanations of sub-state diplomacy, however, adopt as their starting point the multi-national character of the modern nation-state and identify sub-state nationalism and identity politics as the primary drivers of sub-state diplomacy (see, for example, Sharafutdinova 2003; Lecours and Moreno 2003; Kincaid 1990). For example, Lecours and Moreno (2003:267-289) argue that the diplomacy of SNGs conceived in the context of multi-national states is more than the external manifestations of the domestic functions of these actors. In other words, sub-state diplomacy represents the purposeful projection of new actors on the world stage. The foreign relations of SNGs in this sense are seen as an integral component of a project concerned with identity and political legitimacy as SNGs seek to actively develop an international personality that would resonate with their domestic quest for greater autonomy and the recognition of their distinctiveness. In the same tradition, Kincaid $(1990 ; 2002)$ introduced the concept of constituent diplomacy to interpret the foreign relations of SNGs as one of the manifestations of the crisis of contested sovereignty in multi-national societies. He reasons that, because constituent units in multi-national societies are co-sovereign constitutional polities with the federal government, they are equally partners with their national governments in formulating and executing foreign policy. From this perspective, sub-state diplomacy or constituent diplomacy, as Kincaid prefers to call it, cannot be considered to be inferior to the diplomacy of nation-states.

Sub-state diplomacy inspired by nationalism would vary in intensity, depending on the ultimate goals of the regional elite. These goals could range from promoting the distinct identity and culture of a sub-national entity, to maximising its political autonomy within the broader federal polity. In some extreme cases, sub-state diplomacy associated with an identity-building project could take the form of preparing the way for an envisioned independence, as was the case with the Canadian province of Quebec in the 1990s (Keating 1999:13; Sharafutdinova 2003:615-616).

For scholars such as Brian Hocking, sub-state diplomacy is best understood as a function of the exigencies of globalization and economic interdependence. Hocking conceptualizes the foreign relations of SNGs as an integral part of a new multi-layered or catalytic diplomacy, a concept he employs to identify ongoing transformations in diplomatic practice brought about by increasing globalisation 
and interdependence. From this perspective, sub-state diplomacy, or what Hocking refers to as the "localisation of foreign policy", is not seen as a process of autonomous actors that challenge the hegemony of the nation-state in foreign affairs. Instead, it is interpreted as a demonstration of the capacity of nation-states to adapt to an increasingly complex policy environment by co-opting or tapping into the more fluid agency of other kinds of international actors, including SNGs (Hocking 1993; Hocking 1996; Hocking 1999). This neo-liberal perspective of sub-state diplomacy is inspired by an extensive body of literature that is devoted to understanding the interplay between global and local dynamics in an increasingly interdependent and complex system. This trend is depicted by concepts such as complex interdependence, glocalisation and fragmegration, which, among other things, point to the growing internationalisation of the domestic policy agenda and the corresponding increase in international actors, as different substate and non-state actors try to promote and defend their interests in a system of perforated sovereignties (see, for example, Keohane and Nye 1977; Rosenau 1997; Swyngedouw 2004).

A variant of this interpretation of sub-state diplomacy views the phenomenon as an offshoot of regional integration projects, exemplified by the European Union (EU). The argument here, promoted through concepts such as plurinational diplomacy and multi-level governance, is that federal states that transfer authority over aspects of their domestic policy agenda to supra-national institutions inevitably invite their SNGs to the foreign policy scene, given that many of the domestic policy issues that are regionalised often fall exclusively or partly under the jurisdiction of the latter. This gives rise to what Hooghe and Marks (quoted in Bache and Flinders 2004:3) refer to as, "a system of continuous negotiation among nested governments at several territorial tiers". Sub-state diplomacy is thus seen as an inevitable response to the system of interlocking sovereignties engendered by far-reaching regional integration projects. This interpretation of sub-state diplomacy is significant in that it captures the efforts of SNGs dedicated to acquiring the competence to participate in the decision-making processes of supra-national regional institutions, either through direct representation or by using internal foreign policy processes to influence the positions that their states adopt in regional institutions (Aldecoa 1999:83-89).

Without a doubt, these myriad conceptualisations and interpretations of sub-state diplomacy are useful in enriching our understanding of a phenomenon which is as complex as it is fast evolving. Despite the lack of a comprehensive theory of sub-state diplomacy, as the foregoing suggests, the growing literature on the phenomenon has been able to provide useful insights into some of the general drivers and determinants of the diplomacy of SNGs, as well as the strategies used by these entities to actualize their international agency. However, the 
different theoretical accounts discussed above have been insufficient in providing satisfactory explanations of the manifestation and evolution of the phenomenon in specific political contexts, limiting our ability to explain observed variations in substate diplomacy both across countries and within the same country across time.

An alternative research agenda pioneered by Lecours, as well as Bursens and Deforche, has recently proposed the use of historical institutionalism as a complementary theoretical perspective for the study of sub-state diplomacy. In this regard, Lecours (2002) attempts to explain variations in the foreign activities of SNGs by developing a multi-level explanatory framework which argues that sub-state diplomacy is determined by the interplay of a set of institutional systems located at the sub-national, national, continental and global levels. Similarly, Bursens and Deforche (2010) use historical institutionalism to explain the evolution of the foreign policy competences of SNGs in federal states, with a particular focus on the Belgian case. Their main argument is that the strategies of political actors in any given country with respect to the, "division of foreign policy competences are adjusted by the institutional constraints and opportunities and that the eventual organization of external relations matches the historical path" (Bursens and Deforche 2010:159). This article follows in this tradition by borrowing from the theoretical arguments of historical institutionalism to analyse the manifestation and evolution of sub-state diplomacy in South Africa, as a contribution to the understanding of the uneven development of the practice. Before proceeding to the main task of the article, the next section provides a synopsis of the fundamental assumptions and major arguments of historical institutionalism.

\section{HISTORICALINSTITUTIONALISMANDPOLITICALOUTCOMES}

The central argument running through all strands of new institutional theory is that the choices and behaviour of political actors are mediated by institutions, understood as the formal and informal rules, norms, conventions and political standards prevailing in a particular polity at any given time (Steinmo 2001:570). In other words, the institutional context either serves to constrain or enable political actors as they attempt to translate their preferences into policies. At least three major schools of new institutionalism can be identified. Rational choice institutionalists see institutions largely as exogenous constraints that are designed to structure human interactions. Institutions, from this perspective, serve both to coordinate and constrain the strategic choices of rational political players and, therefore, become instrumental in resolving collective action problems (Shepsle 2008:25). The rational choice perspective is founded on the assumption that human beings are rational individualists who calculate the costs and benefits in the choices they face. 
Therefore, rules are designed and voluntarily complied with, because humans are strategic actors who want to maximize their individual gain (Steinmo 2008:126).

While rational choice theorists' understanding of institutions begins with selfinterested and rational individuals, sociological institutionalists on their part approach institutions from the perspective of society, assuming that humans are essentially social beings who do not just follow rules to maximize their self-interests, but largely do so because it is the appropriate thing to do (Steinmo 2008:126). From this perspective, institutions are social constructs, which embody shared cultural understandings of the way problems are perceived and solutions are sought (Thelen 1999:371). Sociological institutionalists believe institutions structure not only actors' choices, but also their preferences. What is more, sociological institutionalists employ a broad conceptualization of institutions to include not only formal and informal rules and procedures, but also symbols, norms and culture (Nichols 2014:483).

Historical institutionalism distinguishes itself from other forms of new institutionalism in that it conceives of institutions as the enduring legacies of specific historical processes or political struggles, which go on to influence the way in which political actors define their interests and objectives. Because institutions are believed to embody the logic of concrete temporal and social orders, historical institutionalists argue that history and historical events play a major role in influencing political choices and outcomes (Thelen 1999:381). Two fundamental claims are embedded in the argument on how historical and institutional contexts influence the outcome of political processes. Firstly, historical institutionalists believe that, "institutions really have a logic of their own, and therefore their creation and development result in consequences unplanned for and unforeseen by political actors" (Lecours 2005:9). The second assumption is rooted in the temporal argument of historical institutionalism and suggests that political choices made at any given point in time, such as the establishment of certain institutions, tend to constrain future options and strategies (Bursens and Deforche 2010:158-159).

However, Thelen has cautioned against treating these different schools of thought as representing distinct and conflicting interpretations of institutions, arguing that, "the walls dividing the three perspectives of new institutionalism have over time been eroded by 'border crossers' who have resisted the tendencies toward cordoning these schools off from each other and have borrowed liberally and often fruitfully where they can in order to answer specific empirical questions" (Thelen 1999:370). An example of such borrowing and cross-fertilization, which is relevant to the present analysis, is the tendency for both historical and sociological institutionalists to, "embrace a more expansive view of institutions, not just as strategic context but as a set of shared understandings that affect the way problems are perceived and solutions are sought" (Thelen 1999:371). Thus, despite our focus on historical institutionalism as the theoretical framework for analysing 
and understanding the development of sub-state diplomacy in South Africa, for the purpose of this article, institutions will be broadly understood as formal and informal rules, norms, procedures and the prevailing political culture.

The concepts of path dependency and critical junctures are used by historical institutionalists to explain the effects of history and historical moments on institutional development and political choices. In its most basic interpretation, path dependency refers to the tendency for political choices and systems emerging from a specific moment in time, or what is often considered as a critical juncture, to reproduce and reinforce themselves to the extent of influencing future choices and processes (Fioretos 2011:376). Rixen and Viola (2009:8) argue that, "sometimes these past choices may have been purely coincidental, or have at the time only been viewed as small and unimportant events but prove to have important consequences later on". Generally, however, critical junctures constitute significant events or political developments, which establish a new institutional pathway or political legacy. Although the institutions that make up this new order may undergo gradual changes in response to changing environmental conditions and ongoing political manoeuvring, henceforth the choices and behaviour of political actors are bound to be constrained by the fundamental logic underpinning the historical institutional trajectory until a new critical juncture sets in (Thelen 1999:387). Krasner explains the historical institutionalist argument on path dependency as follows, "Historical developments are path dependent; once certain choices are made, they constrain future possibilities. The range of options available to policymakers at any given point in time is a function of institutional capabilities that were put in place at some earlier period, possibly in response to very different environmental pressures" (quoted in Nichols 2014:478).

The literature on path dependency contains different perspectives on the mechanisms that make it possible for critical junctures to be self-reinforcing and translated into lasting political legacies (see, for example, Beyer 2000; Thelen 1999:387-401). Two such perspectives are particularly relevant in the context of this article. Firstly, the legitimacy-based argument suggests that institutions are reproduced because actors believe it is the appropriate thing to do, or they regard institutions as legitimate. Secondly, power-based explanations of path dependence argue that particular institutions are maintained because they serve the interest of the dominant political elite who are able to use their power to block alternative institutional pathways (Beyer 2000:4). However, Thelen (1999:385-395) convincingly argues that because institutions are embedded in contexts that are constantly changing, the logic of automatic reproduction and reinforcement suggested in these explanations actually obscures the reality that normative and power shifts resulting from ongoing conflict in the system can disrupt the "lockedin equilibrium" or, at least, render it a politically tenuous path. In this context, she 
introduces the concept of institutional layering to describe processes of gradual institutional change resulting from the creative attempts of certain actors to work around the limitations of existing institutions. As Tsai (2007:214-215) notes, layering involves the establishment of new institutions alongside old ones, a process that may work to dilute the relevance of the old institutions; "This enables the creators of new institutions to avoid direct efforts at reforming politically entrenched institutions". As the analysis in the next section shows, the evolution of sub-state diplomacy in South Africa generally reflects the outcome of path dependent institutional stability and reproduction. Even so, ongoing shifts in the political environment have sometimes enabled subtle attempts to challenge the system.

\section{SOUTH AFRICA'S TRANSITIONAL NEGOTIATIONS AS A CRITICAL HISTORICAL JUNCTURE}

South Africa's political system can best be described as a quasi-federation to the extent that the Constitution underscores and seeks to safeguard the unitary character of the polity, while also creating semi-autonomous sub-national entities (Hayson 2001:504). A good understanding of the manifestation and evolution of sub-state diplomacy in South Africa is not possible outside of the framework of the federal versus unitary tension embodied by this constitutional design, including the historical context and political conflict that produced it. South Africa's interim Constitution of 1993 and the final Constitution of 1996 were both products of political negotiations which enabled the country to make the transition from the oppressive and discriminatory apartheid system to a democratic dispensation. One of the sticking points during these constitutional negotiations was whether a post-apartheid South Africa should adopt a federal or unitary structure. On the one hand, racial and ethnic minority political parties, such as the Inkatha Freedom Party (IFP) and the now defunct National Party (NP), advocated for a federal system of government that would curtail the dominance of the African National Congress (ANC), which enjoyed the support of the majority of South Africans. On the other hand, the ANC was fervently opposed to the federal idea mainly because it would undermine its reconstruction and nation-building agenda, but also because it resonated with the apartheid regime's "Bantustan" policy and was also advocated by Afrikaner extremist groups. The adoption of federal principles alongside a commitment to centralise government was therefore a conflict resolution mechanism which helped South Africa make a relatively peaceful transition to democracy (Steytler and Mettler 2001; Moller 2000:49).

This political compromise can also be interpreted as a critical historical juncture, which established the institutional path that would significantly shape 
subsequent political processes in post-apartheid South Africa, including the degree of latitude available to the country's SNGs to engage in foreign affairs. The outcome of the transitional negotiations of the 1990s allowed for relatively autonomous sub-national entities with a mandate to localise national development efforts, while also contributing to deepening democracy in South Africa. However, the interplay between widespread constitutional safeguards in favour of national unity and the ANC's subsequent dominance of the political environment in South Africa means that the idea of relative sub-national autonomy and the promise of a decentralised polity have over time given way to the emergence of a centralised institutional system.

The constitutional allocation of foreign affairs competence in the final Constitution of 1996 did not only embody the political conflict between centrifugal and centripetal forces in the South African polity at the time, but also reflected the emerging hegemony of the ANC and its preference for a centralised system of government. Affirming the supremacy of the national government over foreign affairs, section 231(1) of the 1996 Constitution stipulates that the power to negotiate and sign all international treaties is the exclusive prerogative of the national executive. The Constitution also entrusts responsibility for receiving and recognizing foreign diplomatic and consular representatives, as well as appointing diplomatic and consular representatives to the president. Moreover, none of the schedules of the Constitution outlining the exclusive competences of provincial and municipal governments, and those they exercise concurrently with the national government, makes mention of foreign affairs.

As Devenish (1998:170) observes, all residual powers are vested in the national government. However, reflecting the influence of advocates of a decentralised system of government, section 231(2) of the Constitution mandates that international agreements that are not of a technical, administrative or executive nature, and those requiring ratification or accession, must be approved by both the National Assembly and at least six of the nine provinces represented in the National Council of Provinces (NCOP). Additionally, the Constitution allows for the national and provincial governments to concurrently legislate, formulate, and implement policies on a long list of functional areas. Many of the matters that fall under this concurrent list such as health, education and the environment have become increasingly internationalised. The principles of cooperative government outlined in chapter 3 of the Constitution, also mandates inter-sphere consultation and coordination on matters of common interest. These provisions have been interpreted as granting some degree of foreign affairs competence to provincial and local governments (Murray and Nakhjavani 2009:218-219). Even so, far-reaching supremacy clauses embedded in the Constitution serve to curtail the manoeuvring space available to SNGs in this regard. 
Fritz Nganje • Historical institutionalism and the development of sub-state diplomacy in South Africa

\section{THE EFFECTS OF A CENTRALISED POLITICAL CULTURE ON THE DEVELOPMENT OF SUB-STATE DIPLOMACY IN SOUTH AFRICA}

With the ANC consolidating its hegemony in post-apartheid South Africa's political landscape, the dominant political culture in the system has been in favour of the centralising logic of this institutional path. As Malherbe (2008:47-49) argues, the general constitutional stipulations for cooperative government and subsequent intergovernmental processes have been used by the national government to promote a centralised system of government that has steadily eroded the relative autonomy of SNGs (see also Lorimer 2001; Simeon and Murray 2001). Although in the immediate years following the adoption of the Constitution provinces displayed some degree of activism in safeguarding their relative autonomy (Zondi 2012:52), for the most part, provincial governments have limited themselves to implementing legislation and policies that emanate from the centre. Besides the continued dominance of the ANC in South African politics, this institutional trajectory has over the years been reproduced and reinforced by the evaporation of the "underlying conflicts and federal impetus" that triggered the constitutional compromise (Steytler and Mettler 2001:93), as well as the generally weak political and administrative capacities in provincial and local governments (Lorimer 2001; Simeon and Murray 2001).

The interpretation of the constitutional allocation of foreign affairs competences and the corresponding international involvement of South Africa's SNGs has not been immune from the influence of this institutional culture. Thus, the dominant understanding of the constitutional stipulations outlined above is that the national government is exclusively responsible for foreign affairs. Not surprisingly, since 1994 South Africa's SNGs have been virtually absent from the foreign policy-making processes. Despite the fact that provinces share jurisdiction with the national government over a number of policy areas that have become the subject of South Africa's international relations, very little official consultation takes place between the national and provincial governments on South Africa's foreign policy and international relations (Murray and Nakhjavani 2009:220-222). The role of provinces in treaty-making is also curtailed by the traditions of centralism and hierarchy that have evolved from South Africa's constitutional order and political culture. As noted earlier, the Constitution affords provinces the opportunity, through the NCOP, to represent their interests during the making of certain categories of treaties. However, in practice the NCOP, just like the National Assembly, has often deferred to the authority of the national executive on the making of foreign policy, including the negotiation of international treaties (Ahmed 2009:301; Murray and Nakhjavani 2009:223). 
The predominance of the logic of centralised hierarchy in South Africa's postapartheid institutional culture has, however, not completely silenced the centrifugal impulses in the polity. In the domain of foreign affairs, this has translated into a vibrant international involvement of provincial and local governments on the basis of their developmental mandate derived from the Constitution. Since 1994, all nine provinces, and many of the country's municipalities, have entered into cooperation partnerships with external actors and engaged in diverse forms of international activities mainly to promote the economic interests of their localities, but also to seek development assistance and exchange governance experiences with their foreign peers (Nganje 2014:130-135; Zondi 2012:44-50). Both the ANC and the national government appear to be supportive of the sub-state diplomacy of provincial and local governments, to the extent that the practice is seen as a complementary vehicle for achieving the developmental objectives of South Africa's foreign policy (ANC 2002). In fact, some of the foreign cooperation activities of provincial and local governments have been undertaken in close collaboration with the national government (Nganje 2013:169-174), bringing sub-state diplomacy in South Africa closer to Hocking's notion of multi-layered diplomacy, in which the diplomacy of SNGs is seen as the localisation of the national foreign policy.

Nevertheless, the nature, scope, and efficiency of the international involvement of provincial and local governments, and the extent to which this has been accommodated by the national government has been and continues to be dictated by the institutional path that South Africa has travelled since the end of apartheid. As the preceding discussion of South Africa's institutional environment suggests, sub-state diplomacy in this context derives its legitimacy primarily from arguments that the practice has the potential to contribute to the national project of socioeconomic transformation. Consequently, provinces and municipalities have progressively interpreted their international involvement as nothing more than a developmental project, which is built around the specific needs and capacities of their jurisdictions but recognises Pretoria's supreme authority over South Africa's foreign policy and international relations. In this respect, it has become common practice for provincial and local authorities to preface their international relations strategy documents with a commitment to conduct their foreign activities within the framework of South Africa's foreign policy and national development priorities. For example, the Western Cape's provincial international relations strategy maintains that, "[t]he Constitution of South Africa is clear in its stipulation that international relations [are] a national competence". It then proceeds to underline that, "[t]he Western Cape remains aligned to South Africa's foreign policy whilst articulating a unique regional approach to international relations, particularly with the aim of providing the right conditions for economic growth" (Western Cape Provincial Government 2013:13-24). Moreover, as noted earlier, this developmental approach 
Fritz Nganje • Historical institutionalism and the development of sub-state diplomacy in South Africa

to sub-state diplomacy gives priority to activities and partnerships that result in the flow of foreign direct investments and tourists to the respective province or municipality, promote the access of locally produced goods to foreign markets, as well as attract foreign development assistance.

\subsection{Centralised institutional culture and the coordination of sub-state diplomacy}

The effect of a centralised political culture is also evident on the management of sub-state diplomacy in South Africa. The history of sub-state diplomacy in South Africa is replete with instances of diplomatic blunders, abuse of foreign trips by sub-national officials, as well as general inefficiency in the planning, implementation and coordination of international activities, raising concerns about the actual contribution of sub-state diplomacy to the domestic development agenda (Nganje 2014:135-136). However, in the context of an institutional culture that is uneasy with the idea of autonomous sub-national polities, efforts to decisively address these deficiencies and make sub-state diplomacy more responsive to subnational and national development priorities have proven to be difficult. Although most provincial governments have put in place administrative systems to better manage sub-state diplomacy across different departments and municipalities, a weak culture of accountability in this sphere of government means that compliance with, and enforcement of appropriate regulatory frameworks has been inadequate. With foreign policy and international relations considered to be the preserve of the national government, none of the nine provincial governments has a separate departmental portfolio with a dedicated political head and bureaucracy to provide strategic leadership to sub-state diplomacy. The responsibility to coordinate substate diplomacy is therefore left to international relations units, which, although located in the offices of provincial premiers, do not normally have sufficient political clout or technical capacity to provide strategic guidance on international relations or enforce applicable rules (Nganje 2013:222).

Following the 2009 general elections, the ANC lost control of the Western Cape Province to the Democratic Alliance (DA). The DA's victory in the Western Cape reveals subtle shifts in the political environment, which have been generating multiple pressures on the institutional structure that has evolved in South Africa over the past two decades. Against this backdrop, the DA-led Western Cape has attempted to circumvent the institutional constraints undermining the effective management of sub-state diplomacy by appointing one of its provincial cabinet ministers to provide political leadership to the province's international relations on behalf of the premier. This development is open to two possible interpretations. On the one hand, Zondi (2012:62-63) argues that the Western Cape's innovations in the management of sub-state diplomacy, coupled with the fact that other provinces and metropolitan municipalities are significantly expanding their international 
footprint, signals the possibility of a future challenge to the current institutional order which privileges the centralisation of foreign policy powers. On the other hand, the fact that the DA-led government resorted to appointing an international relations minister without necessarily establishing a full provincial foreign affairs portfolio can be interpreted as deference to, and reinforcement of the dominant understanding that foreign affairs are the exclusive competence of the national government. At best, the Western Cape's actions can be interpreted as an instance of institutional layering through which the province attempts to side-step the constraining effects of the existing institutional order without staging a direct challenge to it. As Mahoney and Thelen note, such a subtle and gradual approach to institutional change is often employed when existing institutional arrangements are open to more than one interpretation or there are powerful veto players in the system that have a stake in preserving the old institutions (Mandelkern 2014:4). It should be pointed out that, although there was no manifest inter-governmental conflict on account of this appointment, the national government took exception to it. Just as it had done in the past when some provinces and municipalities had engaged in embarrassing and wasteful international activities, Pretoria did not hesitate to remind provincial and local governments that foreign affairs was the prerogative of the national government (Parliamentary Monitoring Group 2012).

The dominant political narrative that the domain of foreign affairs is the competence of the national government has also shaped the nature of Pretoria's support for the foreign activities of provincial and local governments, with serious implications for the coordination and efficiency of sub-state diplomacy in South Africa. In the wake of concerns over poorly planned, weakly monitored and generally uncoordinated international involvement by provincial and local governments, different institutions of the national government, including the Department of International Relations and Cooperation (DIRCO); the Department of Cooperative Governance and Traditional Affairs (COGTA); and the International Cooperation, Trade and Security (ICTS) cluster of the national cabinet, ${ }^{3}$ have, since the late $1990 \mathrm{~s}$, adopted a number of initiatives aimed at engendering greater efficiency and coherence in the conduct of sub-state diplomacy (Nganje 2013:89-92). However, against the backdrop of perceptions that provinces and municipalities do not have the constitutional competence to engage in foreign relations, these interventions have often been half-hearted, intermittent and generally inadequate. This is reflected in, for example, the reluctance of DIRCO to extend its specialised

3 Until 2009, DIRCO was known as the Department of Foreign Affairs, while COGTA was called the Department of Provincial and Local Government. The ICTS cluster was formerly referred to as the International Relations, Peace and Security Cluster. 
diplomatic training to sub-national officials. ${ }^{4}$ Moreover, consistent with the idea of an institutional hierarchy in which the national government has the final say on foreign policy issues, Pretoria's interventions to coordinate sub-state diplomacy have often come with a supervisory undertone. Although sub-national officials generally acquiesce to the national government's overall authority on matters of foreign affairs, perceptions that coordinating measures are intended to control rather than facilitate sub-state diplomacy have tended to weaken compliance with, and undermine the effectiveness of such measures. This is the case with the most recent effort to coordinate sub-state diplomacy at the national level through a Consultative Forum on International Relations (CFIR). Established in 2008 to encourage greater coordination, information-sharing and accountability among international relations stakeholders in the three spheres of government, the forum and its accountability mechanisms have had limited impact on the efficiency of sub-state diplomacy mainly because of the erratic compliance and participation of sub-national officials, but also because of insufficient leadership at the level of DIRCO.

The legitimacy-based and power-based arguments of path dependency provide useful insights into how the centralising and hierarchical logic of South Africa's institutional pattern has been reproduced, sustained and reinforced in the domain of foreign affairs, notwithstanding the relative constitutional autonomy of SNGs that has increasingly put pressure on the system. In the first instance, it should be underscored that the greatest source of legitimacy for successive postapartheid administrations has been their commitment, either real or perceived, to transforming the divisive and poverty-inducing legacy of apartheid. The shared understanding within the polity that realising this goal requires national unity and oneness of purpose continues to provide widespread legitimacy for the culture of centralised decision-making, even among sub-national officials. Thus, together with the ANC's organizational culture of democratic centralism and the limited capacity of most provinces and municipalities, the pervasive appeal of the transformation discourse means that sub-national officials, especially those in provinces and municipalities controlled by the ANC, have generally considered it appropriate to acquiesce to the national government's authority over policy issues, including in the domain of foreign affairs. The ascendance of the DA in the Western Cape is perhaps the single most important political development in the past two decades that has brought significant pressure on the current institutional arrangement. However, as noted earlier, although this development has been accompanied by some degree of dynamism in sub-national politics and introduced an element of conflict to inter-governmental relations processes, it has not been able to disrupt the entrenched political culture of centralised decision-making because the balance of

4 Personal conversations with officials at DIRCO and provincial international relation units in Gauteng, North West and KwaZulu-Natal from 2010-2014. 
power in the system remains in favour of the ruling ANC. Consistent with powerbased explanations of path dependence, the ANC has used its majority in the other eight provincial legislatures to curtail the influence that the DA-run Western Cape could have in important inter-governmental relations forums such as the NCOP, thereby preventing any significant shift from the current institutional trajectory.

\section{CONCLUSION}

This article draws on theoretical insights from historical institutionalism to discuss the development of sub-state diplomacy in South Africa against the backdrop of recent academic scholarship that is dedicated to explaining the global variation of the phenomenon. The article is built around the premise that the political negotiations that allowed South Africa to make a relatively peaceful transition from the apartheid system to a democratic dispensation constitute a critical juncture in the history of the country. This is because the constitutional design that emerged out of the compromise between the major political actors produced an institutional pathway that has significantly shaped political processes in South Africa over the past two decades.

Although the Constitution sought to accommodate the centrifugal impulses that prevailed in the polity at the time by creating relatively autonomous subnational entities, it nonetheless created a governing hierarchy that conformed to the preference of the majority ANC for a centralised system of government. The subsequent consolidation of the ANC's hegemony in post-apartheid South Africa's political landscape has therefore been accompanied by the reproduction and reinforcement of the centralising logic of this institutional path, at the expense of the idea of relative sub-national autonomy. In this context, not only have provincial and local governments been shut out of the foreign policy-making process, but their direct involvement in international relations has been constrained by the dominant understanding that matters of foreign affairs are the competence of the national government.

The article notes that ongoing shifts in the political environment, exemplified chiefly by the DA's electoral victory in the Western Cape in 2009 and the growing economic influence and political confidence of a number of provinces and cities, have been exerting subtle pressures on current institutional arrangements, including those that define the appropriate behaviour of actors on matters of foreign affairs. However, because the ANC is still the dominant political player in South Africa, there is yet to be any significant transformation of the historical institutional pathway. As the example of institutional layering by the DA-led Western Cape suggests, it is anticipated that, rather than attempt to directly challenge the entrenched status quo in a political system where national structures of the ANC still hold veto power, more 
Fritz Nganje • Historical institutionalism and the development of sub-state diplomacy in South Africa

provincial and local governments will resort to creative measures to circumvent the system in a bid to further their international interests.

\section{LIST OF SOURCES}

African National Congress 2002. Policy Discussion Documents: International relations, $51^{\text {st }}$ National Conference, August.

Ahmed, AK 2009. "The role of Parliament in South Africa's foreign policy development process: Lessons from the United States' Congress", South African Journal of International Affairs (16)3, December:291-310.

Aldecoa, F 1999. "Towards Plurinational diplomacy in the deeper and wider European Union (1985-2005)". In: F Aldecoa and M Keating (eds), Paradiplomacy in action: The foreign relations of sub-national governments. London: Frank Cass Publishers, pp. 82-94.

Bache, I and M Flinders 2004. "Themes and issues in multilevel governance". In: I Bache and M Flinders (eds) Multilevel governance. Oxford: Oxford University Press, pp. 1-4.

Beyer, J 2000. "The same or not the same: On the variety of mechanisms of path dependence", International Journal of Social Sciences (5)1, 2000. Online, <https:// www.wiso.uni-hamburg.de/fileadmin/sowi/soziologie/institut/Beyer/Beyer_IJSS. pdf $>$, accessed 12 July 2015.

Bursens, P and J Deforche 2010. "Going beyond paradiplomacy? Adding historical institutionalism to account for regional foreign policy competences", The Hague Journal of Diplomacy 5, 2010:151-171.

Bursens, P and F Massart-Pierard 2009. "Kingdom of Belgium". In: H Michelmann (ed.), Foreign relations in federal countries. Montreal: McGill-Queen's University Press, pp. 91-113.

Devenish, GE 1998. A commentary on the South African Constitution. Durban: Butterworths.

Duchacek, I 1990. "Perforated sovereignties: Towards a typology of new actors in international relations". In: HJ Michelmann and P Soldatos (eds), Federalism and international relations. Oxford: Clarendon Press, pp. 1-33.

Fioretos, O 2011. "Historical institutionalism in international relations", International Organization (65)2:367-399. 
Hayson, N 2001. "Federal features of South Africa's Constitution". In: A Penelope and S Ellmann (eds), The post-apartheid constitution: Perspectives on South Africa's basic law. Johannesburg: Witwatersrand University Press, pp. 504-524.

Hocking, B 1993. Localising foreign policy: Non-central governments and multilayered diplomacy. London: Macmillan.

Hocking, B 1996. "Bridging boundaries, creating linkages: Non-central government and multi-layered policy environments", WeltTrends 11:36-51.

Hocking, B 1999. "Patrolling the 'frontier': Globalization, localization and the 'actorness' of non-central governments". In: F Aldecoa and M Keating (eds) Paradiplomacy in action: The foreign relations of sub-national governments. London: Frank Cass Publishers, pp. 17-39.

Hrbek, R 2009. "Federal Republic of Germany". In: H Michelmann (ed.), Foreign relations in federal countries. Montreal: McGill-Queen's University Press, pp. 141-167.

Keating, M 1999. "Regions and international affairs: Motives, opportunities and strategies". In: F Aldecoa and M Keating (eds), Paradiplomacy in action: The foreign relations of sub-national governments. London: Frank Cass Publishers, pp. 1-16.

Keohane, RO and JS Nye 1977. Power and interdependence: World politics in transition. Boston: Little, Brown and Company.

Kincaid, J 1990. "Constituent diplomacy in federal polities and the nation-state: Conflict and cooperation". In: HJ Michelmann and P Soldatos (eds), Federalism and international relations. Oxford: Clarendon Press, pp. 45-76.

Kincaid, J 2002. "Foreign relations of sub-national units". In: R Blindenbacher and A Koller (eds), Federalism in a changing world: Learning from each other. Montreal and Kingston: McGill-Queen's University Press, pp. 74-96.

Lecours, A 2002. "Paradiplomacy: Reflections on the foreign policy and international relations of regions", International Negotiation (7)1:91-114.

Lecours, A and L Moreno 2003. "Paradiplomacy: a nation-building strategy? A reference to the Basque Country". In: A Gagnon, M Guibernau, M and F Rocher (eds), The conditions of diversity in multinational democracies. Montreal: Institute for Research on Public Policy, pp. 267-292.

Lecours, A (ed.) 2005. New institutionalism: Theory and analysis. Toronto: University of Toronto Press. 
Fritz Nganje • Historical institutionalism and the development of sub-state diplomacy in South Africa

Lorimer, J 2001. "The ANC, the opposition and prospects for federalism in South Africa", Federations: What's New in Federalism Worldwide (1)2, January, $<$ http://www.forumfed. org/libdocs/Federations/V1N2-za-Lorimer.htm>, accessed 20 June 2015.

Malherbe, R 2008. "The future of provinces: Constitutional and structural aspects". In: P de Villiers (ed.). Review of provinces and local governments in South Africa: Constitutional foundations and practice. Johannesburg: Konrad Adenauer-Stiftung, pp. 45-58.

Mandelkern, R 2014. "How does institutional layering work? An agent-centred perspective". $4^{\text {th }}$ Annual General Conference of the European Political Science Association, Edinburgh, 19-21 June.

Moller, B 2000. "Pan-Africanism and federalism", Perspectives on Federalism (2)3:38-77.

Murray, C and SA Nakhjavani 2009. "Republic of South Africa". In: H Michelmann (ed.), Foreign relations in federal countries. Montreal: McGill-Queen's University Press, pp. 211-239.

Nganje, F 2013. Paradiplomacy: A comparative analysis of the international relations of South Africa's Gauteng, North-West and Western Cape provinces. $\mathrm{PhD}$, University of Johannesburg.

Nganje, F 2014. "The developmental paradiplomacy of South African provinces: Context, scope and the challenge of coordination", The Hague Journal of Diplomacy (9)2:119-149.

Nichols, PM 2014. "Forgotten linkages: Historical institutionalism and sociological institutionalism and analysis of the World Trade Organization", University of Pennsylvania Journal of International Law (19)2:461-511.

Parliamentary Monitoring Group 2012. "SA strategy in driving economic diplomacy". Department of International Relations and Cooperation Briefing, 19 September, <https://pmg.org.za/committee-meeting/14911/>, accessed 25 July 2015.

Rixen, T and L Viola 2009. "Uses and abuses of the concept of path dependence: Notes towards a clearer theory of institutional change". International Summer School on the Logic of Self-reinforcing Processes in Organizations, Networks and Markets, Berlin, 13-17 July.

Rosenau, JN 1997. Along the domestic-foreign frontier: Exploring governance in a turbulent world. Cambridge: Cambridge University Press. 
Sharafutdinova, G 2003. "Paradiplomacy in the Russian regions: Tatarstan's search for statehood”, Europe-Asia Studies (55)4, June:613-629.

Shepsle, KA 2008. "Rational choice institutionalism". In: S Binder, R Rhodes and B Rockman (eds). Oxford handbook of political institutions. Oxford: Oxford University Press, pp. 23-38.

Simeon, R and C Murray 2001. "Multi-sphere governance in South Africa: An interim assessment", Publius: The Journal of Federalism (31)4, Autumn:65-92.

Steinmo, S 2001. "The new institutionalism”. In: B Clark, B and J Foweraker (eds), The encyclopaedia of democratic thought. London: Routledge, pp. 570-574.

Steinmo, S 2008. "Historical institutionalism". In: D Porta and M Keating (eds), Approaches and methodologies in the social sciences: A pluralist perspective. Cambridge: Cambridge University Press, pp. 118-138.

Steytler, N and J Mettler 2001. "Federal arrangement as a peacemaking device during South Africa's transition to democracy", Publius: The Journal of Federalism (31)4, Autumn:93-106.

Swyngedouw, E 2004. “Globalisation or 'glocalisation'? Networks, territories and rescaling”, Cambridge Review of International Affairs (17)1, April:25-48.

Thelen, K 1999. "Historical institutionalism in comparative politics", Annual Review of Political Science 2, June:369-404.

Tsai, KS 2007. Capitalism without democracy: The private sector in contemporary China. New York: Cornell University Press.

Western Cape Government 2013. International relations strategy, September.

Zondi, S 2012. "The international relations of South African provinces and municipalities: An appraisal of federated diplomacy". In: C Landsberg and J van Wyk (eds), South African Foreign Policy Review. Volume 1. Pretoria: IGD \& AISA, pp. 42-67. 